\title{
INTENCIÓN DE COMPRA DEL CONSUMIDOR ORGANIZACIONAL DE CHILE REGIONAL EN EL ESTADO DE PUEBLA, MÉXICO
}

\section{PURCHASING INTENTION OF THE ORGANIZATIONAL CONSUMER OF REGIONAL CHILI PEPPER IN THE STATE OF PUEBLA, MÉXICO}

\author{
Rogelio Pérez-Vargas $^{1}$, Juan Morales-Jiménez ${ }^{1 *}$, Higinio López-Sánchez ${ }^{1}$, A. Velia Ayala-Garay ${ }^{2}$ \\ 1'Colegio de Postgraduados Campus Puebla (roleon25@hotmail.com, minitos@yahoo.com, \\ higiniols@colpos.mx).²INIFAP (ayala.alma@inifap.gob.mx).
}

\begin{abstract}
RESUMEN
La producción de chile en el estado de Puebla enfrenta dificultades para su permanencia depende, entre otras cosas, competir eficazmente en el mercado, donde la información de la cadena de valor es crucial para generar opciones para la comercialización. El objetivo de este trabajo fue conocer la intención y conducta de compra del consumidor organizacional para satisfacer sus necesidades de chile con la producción regional. Se aplicó una encuesta a 36 consumidores industriales para determinar su intención de compra y se plantearon preguntas cerradas para conocer su conducta de compra. Se realizó un análisis de fiabilidad, se hicieron tablas de contingencia y una correlación de Spearman. Los chiles de mayor consumo fueron el jalapeńo, el chipotle y el serrano. Las características de mayor importancia para los consumidores fueron la frescura, la ausencia de material extrańo y que no tenga dańo físico. La central de abasto local es el principal sitio de compra de la micro y pequeña empresa, mientras que la gran empresa se abastece de una red nacional. Se determinó que existe una intención positiva de compra de chile regional, siempre y cuando se cumplan las condiciones de precio competitivo, calidad del fruto $\mathrm{y}$ aspectos fiscales.
\end{abstract}

Palabras clave: Capsicum spp., consumidor organizacional, mercado intermedio, preferencia.

\section{INTRODUCCIÓN}

L a producción de chile se ha incrementado a nivel mundial. En 2000 se cosecharon 23.1 millones de toneladas para pasar a 31.2 millones en 2009 y 31.5 millones en 2014 (FAOSTAT,

* Autor responsable $*$ Author for correspondence.

Recibido: diciembre, 2015. Aprobado: noviembre, 2016.

Publicado como ARTÍCULO en ASyD 14: 599-615. 2017.
Abstract

Chili pepper production in the state of Puebla faces difficulties and for its permanence depends, among other things, on competing effectively in the market, where the information of the value chain is crucial to generate options for commercialization. The objective of this study was to understand the purchasing intention and conduct of the organizational consumer to satisfy its needs for chili with regional production. A survey was applied to 36 industrial consumers to determine their purchasing intention and closed questions were set out to understand their purchasing conduct. A reliability analysis was performed, contingency tables were made, and a Spearman correlation. The chili peppers of highest consumption were jalapeño, chipotle and serrano. The characteristics of greatest importance for consumers were freshness, absence of strange material and no physical damage. The local wholesale market is the main purchasing site of micro- and small-scale businesses, while large-scale businesses are supplied by a national network. It was determined that there is a positive purchasing intention for regional chili, as long as the conditions of competitive price, quality of the fruit, and fiscal aspects are fulfilled.

Key words: Capsicum spp., organizational consumer, intermediate market, preference.

\section{INTRODUCTION}

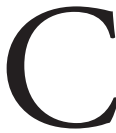
hili production has increased at the global level. In 2000, 23.1 million ton were harvested, increasing to 31.2 million in 2009 and 31.5 million in 2014 (FAOSTAT, 2014). Its increase responds to the commercialization and consumption of products processed based on chili (Jäger et al., 2013). México is one of the main chili-producing countries, with a production of 
2014). Su incremento obedece a la comercialización y consumo de productos procesados a base de chile (Jäger et al., 2013). México es uno de los principales países productores de chile, con una producción de 2.2 millones de toneladas (FAOSTAT, 2014) en una superficie sembrada de 149 mil hectáreas y una participación de 12 mil productores (SAGARPA, 2012). Sin embargo, uno de los principales problemas que limitan su producción en el país son los altos costos de insumos, comercialización deficiente, escasa organización para la producción, créditos insuficientes, entre otros (Galindo, 2007).

El estado de Puebla no escapa a la influencia de estos factores y la tendencia inversa a la nacional en el periodo comprendido de 2000 a 2010 el rendimiento de chile verde en el estado se redujo en $8 \%$, la producción en $11 \%$ y la superficie sembrada en $5 \%$ (SAGARPA, 2010), y se debe principalmente a la falta de mercado. Al respecto, Huerta y Jaramillo (2010) consideran que el problema de la comercialización del picante en Puebla es un elemento que desalienta su producción, ya que no cuenta con un mercado fijo.

Respecto a los estudios enfocados a buscar opciones de mercado, a través de una encuesta aplicada a consumidores, Rodríguez (2005) encuentra que en nueve ciudades de los Estados de Coahuila, Nuevo León y Tamaulipas existen altas preferencias del consumidor final por los chiles jalapeño $(37.3 \%)$, piquín (29.6\%) y serrano (24.0\%). Castellón et al. (2012) identifican en los valles Centrales de Oaxaca existe alta preferencia del consumidor final por el chile jalapeño, de árbol, de agua y serrano. Entre los chiles regionales preferidos por su sabor y grado de picor, además del de agua, destacan el Paradito y Tusta; las formas preferidas de consumo son en salsas, rellenos y rajas. Por lo que atañe al tipo de consumidores, García (2013) encuentra en Lima, Perú que el segmento potencial para la introducción de variedades de chiles nativos está integrado por personas jóvenes, del sexo masculino, de clase media que disfrutan este producto.

La mayoría de los estudios de mercados agrícolas se han enfocado a estudiar al consumidor final, dejando de lado al consumidor intermedio o agroindustrial. Al respecto, Manrique (2014) menciona que se necesitan más investigaciones para entender los procesos de abasto de este consumidor. Sin embargo, no se reportan estudios en el comportamiento
2.2 million tons (FAOSTAT, 2014) in a surface sown of 149 thousand hectares and a participation of 12 thousand producers (SAGARPA, 2012). However, one of the main problems that limit its production in the country is the high costs of inputs, deficient commercialization, scarce organization for production, insufficient credits, among others (Galindo, 2007).

The state of Puebla does not escape the influence of these factors and in the period between 2000 and 2010 with a trend inverse to the national one, the yield in green chili in the state was reduced in $8 \%$, the production in $11 \%$ and the sown surface in $5 \%$ (SAGARPA, 2010), and it is mainly because of the lack of market. In this regard, Huerta and Jaramillo (2010) consider that the problem of commercialization of chili in Puebla is an element that discourages its production, since it doesn't have a fixed market.

With regard to the studies focused on seeking market options, through a survey applied to consumers, Rodríguez (2005) finds that in nine cities of the states of Coahuila, Nuevo León and Tamaulipas there are high preferences from the final consumer for jalapeño (37.3\%), piquín (29.6\%) and serrano $(24.0 \%)$ chili peppers. Castellón et al. (2012) identified in the central valleys of Oaxaca that there is a high preference from the final consumer for jalapeño, árbol, agua and serrano chili peppers. Among the preferred regional chili peppers because of their flavor and degree of burning aftertaste, in addition to the chili de agua, Paradito and Tusta stand out; the preferred forms of consumption are in sauces, fillings and slices. In terms of type of consumers, García (2013) finds that in Lima, Perú, the potential segment for introduction of native chili varieties is made up of young, masculine, middleclass people who enjoy this product.

Most of the agricultural market studies have been focused on studying the final consumer, leaving aside the intermediate or agroindustrial consumer. In this regard, Manrique (2014) mentions that more studies are needed to understand the supply processes of this consumer. However, no studies are reported about the purchasing behavior, preferences, and purchasing intention of the organizational consumer that uses chili pepper as main input, so it is necessary to generate information to seek out market alternatives and foster production of the crop in the region. These 
de compra, preferencias e intención de compra del consumidor organizacional que utiliza el chile como insumo principal, por lo que es necesario generar información para buscar alternativas de mercado e incentivar la producción del cultivo en la región. Estos elementos son relevantes para el análisis y la toma decisiones que orienten y organicen a los productores de chile en el estado de Puebla, así como llevar a cabo políticas para incidir en las condiciones socioeconómicas de las zonas productoras de chile.

La intención de compra es uno de los aspectos más relevantes en el comportamiento del consumidor, entendido como un proceso recíproco en la interacción entre los consumidores y los productores al momento de la adquisición del bien o servicio (Solomon, 2013); además, la intención permite utilizarla como una medida de predicción de conducta de compra posterior o sucesiva (Grewal et al., 1998; Morwitz y Schmittlein, 1992). La intención de compra es "el grado en que al consumidor le gustaría comprar determinado producto en el futuro" (Chu y Lu, 2007). $\mathrm{Al}$ respecto, Peña (2014) indica que la importancia de la intención de compra radica en cuándo se quiere usar un nuevo canal para llegar a los consumidores, siendo que esta es considerada un indicador para prever el comportamiento real del consumidor; Soto et al. (2006) mencionan que la intención del comportamiento y el control percibido también influyen, es decir, la posibilidad de obtener los productos por su precio, su disponibilidad u otros factores.

El comportamiento del consumidor implica tener presente un conjunto de acciones cuando busca, compra, evalúa, usa y dispone de los bienes con el objeto de satisfacer sus necesidades. En dicha satisfacción es importante identificar por qué compra algún producto, cuándo lo adquiere, quién lo adquiere, cómo lo necesita, dónde se abastece, cuánto del producto consume y cómo lo utiliza. Dicho comportamiento refiere a dos tipos de entes: el consumidor individual y el organizacional -incluye mercados industriales, mercados gubernamentales o institucionales y mercados intermediarios- (Schiffman y Kanuk, 2010). En este sentido (Kotler y Keller, 2009; Mannarelli, 1978) indican que existen los llamados "mercados industriales", que se refiere a la industria que utiliza materia prima de diversa procedencia, como la agropecuaria, y son empleados para la producción de otros bienes. En este requerimiento de insumos es importante conocer qué factores $o$ variables (internas-externas) influyen en el proceso elements are relevant for the analysis and decision making that guide and organize chili producers in the state of Puebla, as well as implementing policies to impact the socioeconomic conditions of the chiliproducing zones.

The purchasing intention is one of the most relevant aspects in the consumer's behavior, understood as a reciprocal process in the interaction between consumers and producers at the moment of acquiring the good or service (Solomon, 2013); in addition, the intention allows using it as a measure of prediction of later or successive purchasing behavior (Grewal et al., 1998; Morwitz and Schmittlein, 1992). The purchasing intention is "the degree to which the consumer would like to purchase a specific product in the future" (Chu and $\mathrm{Lu}, 2007$ ). In this regard, Peña (2014) indicates that the importance of the purchasing intention lies in identifying the time when there is the desire to use a new channel to reach the consumers, with this being considered an indicator to foresee the actual behavior of the consumer; Soto et al. (2006) mention that the purchasing intention of the behavior and control perceived also have an impact, that is, the possibility of obtaining products with their price, their availability or other factors.

The consumer's behavior implies having in mind a set of actions when he/she is seeking, purchasing, evaluating and using goods with the objective of satisfying his/her needs. In this satisfaction it is important to identify why he/she purchases a specific product, when he/she acquires it, who acquires it, how he/she needs it, where it is supplied, how much of the product is consumed and how it is used. This behavior describes two types of entities: the individual consumer and the organizational consumer - including industrial markets, government or institutional markets, and intermediate markets (Schiffman and Kanuk, 2010). In this sense, Kotler and Keller (2009) and Mannarelli (1978) indicate that there are the so-called "industrial markets", which refer to the industry that uses raw material of diverse origin, such as from agriculture and livestock production, and are used for the production of other goods. In this requirement of inputs it is important to understand what factors or variables (internalexternal) influence the process of purchasing decision (Solé, 2003), in addition to establishing which are the preferences of the organizational consumer, which seeks to satisfy the needs of the organization through 
de decisión de compra (Solé, 2003), además de establecer cuáles son las preferencias del consumidor organizacional, que busca satisfacer las necesidades de la organización a través de los atributos del producto, pero también se ve influenciada por las 4 "Ps": producto, precio, plaza y promoción. Se suman los aspectos económicos, tecnológicos, políticos y culturales que dirigen la respuesta de los compradores industriales para elegir el producto, los proveedores, las cantidades y los términos de compra (Manrique, 2014; Armstrong y Kotler, 2003). Grunert (1989); indica que el atributo es cualquier aspecto del producto en sí mismo que es útil para comparar las diferentes alternativas de compra. El objetivo de este trabajo fue conocer la intención y conducta de compra del consumidor organizacional para satisfacer con la producción regional sus necesidades de chile.

\section{Materiales y Métodos}

El estudio se realizó en el Valle de Puebla, ubicado entre las coordenadas $19^{\circ} 03^{\prime}$ de longitud norte y $98^{\circ} 12^{\prime}$ de longitud oeste (INEGI, 1995); limita al norte con el Iztaccíhuatl, al sur con Valsequillo, al este con el Valle de Tepeaca y al occidente con la Sierra Nevada. El valle está rodeado de actividad industrial, producto de la instalación de manufacturas alimenticias, autopartes, metalúrgica, comercio y servicios.

El enfoque de esta investigación se sustentó en un método cuantitativo (Hernández et al., 2010). El diseño fue no experimental y de manera transversal. La investigación correspondió a un estudio de tipo exploratorio y correlacional, puesto que se estableció el grado de relación entre la intención de compra con el precio, la calidad, la cercanía del producto y las características del fruto. El tipo de muestreo fue no probabilístico, se combinó el muestreo de tipo intencional y bola de nieve (Sharon, 2000).

La unidad de muestreo fue el padrón de empresas contenidas en diversas fuentes. La primera correspondió a la Dirección de Agricultura por Contrato perteneciente a la Secretaría de Desarrollo Rural, Sustentabilidad y Ordenamiento Territorial de Puebla. La segunda base es del Directorio Estadístico Nacional de Unidades Económicas (DENUE, 2012), perteneciente al Instituto Nacional de estadística y geografía (INEGI, 2012), y la tercera corresponde al Sistema de Información Empresarial Mexicano (SIEM, attributes of the product, but is also influenced by the 4 "Ps": product, price, post, and promotion. In addition, by the economic, technological, political and cultural aspects which direct the response of industrial buyers to choose the product, the suppliers, the amounts and the terms of purchase (Manrique, 2014; Armstrong and Kotler, 2003). Grunert (1989) indicates that the attribute is any aspect of the product in itself that is useful to compare the different purchasing alternatives. The objective of this study was to understand the purchasing intention and conduct of the organizational consumer to satisfy their need for chili pepper with the regional production.

\section{Materials AND Methods}

The study was performed in Valle de Puebla, located between coordinates $19^{\circ} 03^{\prime}$ of longitude North and $98^{\circ} 12^{\prime}$ of longitude West (INEGI, 1995); it borders north with the Iztaccíhuatl volcano, south with Valsequillo, east with Valle de Tepeaca and west with Sierra Nevada. The valley is surrounded by industrial activity, product of the establishment of food manufacturers, auto parts, metallurgist, commerce and services.

The approach of this study was supported by a quantitative method (Hernández et al., 2010). The design was not experimental and transversal. The research corresponded to a study of exploratory and correlational type, since it established the degree of relation between the purchasing intention and the price, quality, proximity of the product, and characteristics of the fruit. The type of sample was not probabilistic, and sampling of intentional type and snowballing was combined (Sharon, 2000).

The sampling unit was the registry of companies included in various sources. The first corresponded to the Direction of Agriculture by Contract that belongs to the Ministry of Rural Development, Sustainability and Territorial Planning in Puebla. The second base is the National Statistical Directory of Economic Units (DENUE, 2012), belonging to the National Institute of Statistics and Geography (INEGI, 2012), and the third corresponds to the Mexican Entrepreneurial Information System (SIEM, 2013) of the Ministry of Economy. Eighty-nine (89) companies that use chili pepper or its derivatives as inputs were detected, and data were collected from 36 of these companies, 
2013) de la Secretaría de Economía. Se detectaron 89 empresas que usan chile o sus derivados como insumos, y se recolectaron datos de 36 de estas empresas, lo que significó $40.4 \%$ del total de la población. El criterio para el entrevistado fue principalmente que debía conocer el proceso de compra de los insumos y tomar decisiones sobre qué tipo de chile y cantidad a adquirir.

La técnica usada para obtener los datos fueron la entrevista individual y la encuesta. Para recabar la información se usó un cuestionario semiestructurado. Las variables del instrumento se clasificaron en tres bloques: A) el primero contempló datos generales de la industria, sector de producción, tipo de productos que elabora y número de empleados; B) luego se indagó acerca del comportamiento de compra, tipo de chile, lugar y frecuencia de compra, cantidad de kilogramos consumidos, épocas de variación en el consumo y características del fruto; la evaluación del nivel de importancia en los atributos intrínsecos y extrínsecos se realizó a través de una escala tipo Likert, siendo (1) nada importante, (2) poco importante,(3) indiferente, (4) importante y (5) muy importante; y el tercer bloque C) para determinar la intención de compra se empleó la escala propuesta por Kotler et al. (2004) donde los valores fueron: seguramente no (1), probablemente no (2), no sabe (3), probablemente sí (4) y seguramente sí (5).

Se realizó un análisis de fiabilidad del instrumento que midió la consistencia interna del instrumento; se espera que con los ítems mida la misma dimensión teórica; los valores van de 0 a 1 . Se obtuvo un Alfa de Cronbach de $=0.963$, lo que considera al valor de consistencia interna como excelente. Se efectuó un análisis de correlación bivariada de Spearman para medir la magnitud de la relación lineal; las variables oscilan de -1 a 1 . Las variables a las que se aplicó el análisis fueron: intención de compra, precio, cercanía del proveedor, calidad y origen del producto en seco $y$ en verde.

\section{Resultados y Discusión}

En lo que se refiere a la distribución de las empresas por tipo de producto elaborado, $94.4 \%$ se dedica a la fabricación de alimentos y el mayor porcentaje $(63.9 \%)$ a la elaboración de salsas y pasta para mole (Cuadro 1). Los resultados indican que el sector predominante es el alimenticio, relacionando which meant $40.4 \%$ of the total population. The criterion for the interview respondent was mainly that he/she had to understand the purchasing process of inputs and decision making about the type of chili pepper and the amount to be acquired.

The technique used to obtain the data was individual interview and survey. To collect the information, a semi-structured questionnaire was used. The variables of the instrument were classified into three blocks: A) the first contemplated general data about the industry, production sector, type of products it elaborates, and number of employees; B) then, there was inquiry about the commitment for purchasing, type of chili, place and frequency of purchase, amount of kilograms consumed, seasons of variation in the consumption, and characteristics of the fruit; the evaluation of the level of importance in the intrinsic and extrinsic traits was carried out through a Likert type scale, with (1) not important, (2) slightly important, (3) indifferent, (4) important, and (5) very important; the third block, C) to determine the purchasing intention, the scale proposed by Kotler et al. (2004) was used, where the values were: certainly not (1), probably not (2), doesn't know (3), probably yes (4), and certainly yes (5).

A reliability analysis of the instrument that measured the internal consistency of the instrument was performed; it is expected that the same theoretical dimension is measured with the items; the values range from 0 to 1 . Cronbach's Alpha of $=0.963$ was obtained, which considers the internal consistency value as excellent. A bivariate Spearman correlation analysis was performed to measure the magnitude of the linear relation; the variables range from -1 to 1 . The variables to which the analysis responded were: purchasing intention, price, proximity of the supplier, quality and origin of the product dry and green.

\section{Results AND Discussion}

Concerning the distribution of the enterprises per type of product elaborated, $94.4 \%$ is devoted to food elaboration and the highest percentage $(63.9 \%)$ to the elaboration of sauces and paste for mole (Table 1). The results indicate that the predominant sector is the food sector, connecting this product as an important ingredient of Mexican 
Cuadro 1. Productos elaborados y clasificación de tamaño del consumidor organizacional. Table 1. Products elaborated and classification of size of the organizational consumer.

\begin{tabular}{lcccc}
\hline \multirow{2}{*}{ Tipo productos } & \multicolumn{3}{c}{ Clasificación (\%) } & \multirow{2}{*}{ Total } \\
\cline { 2 - 4 } & Micro & Pequeña & Grande & 25.0 \\
Pasta para mole & 25.0 & 0.0 & 0.0 & 38.9 \\
Salsas & 30.6 & 8.3 & 0.0 & 19.4 \\
Conservas & 8.3 & 2.8 & 8.3 & 8.3 \\
Botanas y embutidos & 8.3 & 0.0 & 0.0 & 2.8 \\
Embutidos & 0.0 & 0.0 & 0.0 & 5.6 \\
Shampoo & 5.6 & 0.0 & & \\
\hline
\end{tabular}

De acuerdo con INEGI (2014), la clasificación para micro empresa: 0-10 personas, pequeńa empresa: 11-50 personas; y gran empresa: más de 250 personas ocupadas. According to INEGI (2014), the classification for micro-scale business: 0-10 people; small-scale business: 11-50 people; and large-scale business: more than 250 people employed.

Fuente: elaboración propia con datos obtenidos de la encuesta aplicada a empresas del valle de Puebla. * Source: authors’ elaboration with data obtained from the survey applied to businesses in the valley of Puebla.

este producto como un ingrediente importante de la cocina mexicana, lo que coincide con Rodríguez et al. (2002), quienes mencionan que el chile interviene en la dieta diaria de los mexicanos en diversas presentaciones, sea en verde, seco, polvo, encurtidos, salsas, moles, chiles rellenos, dulces y otras. Castellón et al. (2012) señalan que las formas preferidas de consumo de chile son: salsas $(36.5 \%)$, rellenos $(28 \%)$ o rajas $(11.2 \%)$. En relación con la clasificación por tamaño de los consumidores organizacionales se encontró que el mayor porcentaje corresponde a las microempresas, con $77.8 \%$, y es la microempresa la que produce la mayor cantidad de salsas y pasta para mole. La pequeña empresa se decanta por la producción de salsas y la gran empresa por la de conservas. En este sentido, Ortega (2013) menciona que $60 \%$ de la producción nacional se utiliza en la industria de conservas, $20 \%$ se come fresco y el resto se destina a la elaboración de chipotle. Al respecto, Montes et al. (2004) mencionan que el consumo del chile es muy generalizado en fresco e industrializado en diversas modalidades, influenciado por la preferencia del consumidor.

Las empresas demandan chiles verdes y chiles secos. Los tipos de verdes que más utilizan son: jalapeńo con $41.7 \%$ y chile serrano, $27.8 \%$; para el resto de porcentajes involucra los chiles habanero, chiltepín, manzano, de árbol. Para los chiles secos se emplea más chipotle, con $52.8 \%$; pasilla, con $27.2 \%$; mulato, con $22.2 \%$; el resto de porcentajes involucra a los chiles ancho, guajillo, morita y chiltepín.

Por lo que se refiere a la demanda mensual de chile jalapeño por tipo de empresa se encontró que la gran industria predomina en cantidad utilizada; la cuisine, which agrees with Rodríguez et al. (2002), who mentioned that chili pepper intervenes in the daily diet of Mexican people in various presentations, whether green, dry, powdered, pickled, and in sauces, moles, stuffed chili peppers, sweets and others. Castellón et al. (2012) point out that the preferred forms of chili consumption are: sauces (36.5\%), filling $(28 \%)$ or slices $(11.2 \%)$. In relation to the classification by size of the organizational consumers, it was found that the highest percentage corresponds to micro-businesses, with $77.8 \%$, and it is the micro-business that produces the highest amount of sauces and paste for mole. The small-scale business opts for sauce production and the large-scale business for conserves. In this sense, Ortega (2013) mentions that $60 \%$ of the national production is used in the conserve industry, $20 \%$ is eaten fresh, and the rest is destined to making chipotle. In this regard, Montes et al. (2004) mention that chili pepper consumption is quite generalized fresh and industrialized in various modalities, influenced by the consumer's preference.

The businesses demand green chili peppers and dry chili peppers. The green types that they use most are: jalapeño with $41.7 \%$ and serrano, $27.8 \%$; for the rest of the percentages, they include habanero, chiltepín, manzano, árbol. For dry chili peppers, the one most used is chipotle, with $52.8 \%$; pasilla, with $27.2 \%$; mulato, with $22.2 \%$; the rest of the percentages include ancho, guajillo, morita and chiltepín chili peppers.

Regarding the monthly demand for jalapeño chili pepper per type of business, it was found that the largescale industry predominates in the amount used; the maximum is 8000 ton and the minimum 2744 ton; 


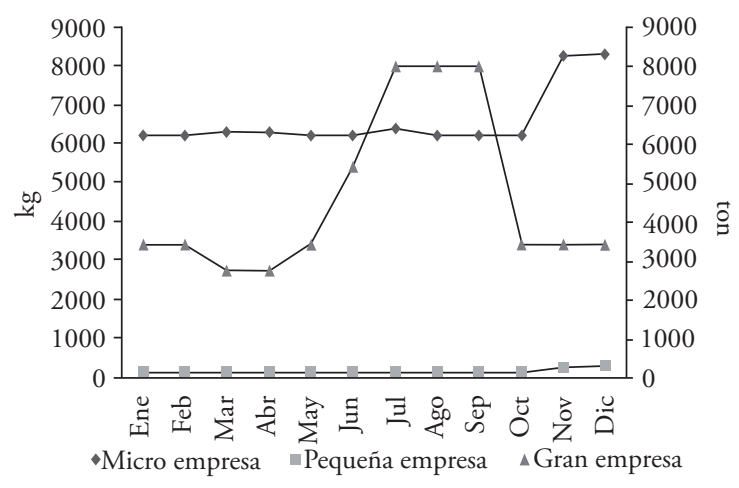

Fuente: elaboración propia con datos de la encuesta aplicada a empresas del valle de Puebla. \&ource: authors' elaboration with data obtained from the survey applied to businesses in the valley of Puebla.

Figura 1. Cantidad consumida mensualmente de chile jalapeno por tipo de empresa, en el valle de Puebla.

Figure 1. Amount consumed monthly of jalapeńo chili pepper per type of business, in the valley of Puebla.

máxima es de 8000 ton y el mínimo de 2744 ton; el comportamiento en su consumo no es constante, ya que presenta fluctuaciones de hasta $191 \%$ durante el año, principalmente en el periodo de julio a septiembre. La micro empresa tiene una demanda máxima de 8.3 ton/mes y mínima de 6.2 ton/mes, con una variación de $33 \%$ durante ańo; y la pequeña empresa, una demanda máxima de $308 \mathrm{~kg} /$ mes y mínimo de $124 \mathrm{~kg} / \mathrm{mes}$; las de la micro y pequeńa empresas tienen un ligero repunte en los meses de noviembre y diciembre (Figura 1). Respecto a las variedades de chile jalapeño que utilizan y requieren son: Perfecto, Seminis, Imperial de la empresa Marseed, Da Vinci, Chichimeca y Mitla.

Respecto a la cantidad de demanda y los meses de compra del chile serrano, donde el consumo es muy diverso en los tres tipos de empresas, la micro empresa alcanza su mayor consumo en mayo, con 954 $\mathrm{kg} / \mathrm{mes}$, y posteriormente desciende a menos de 675 $\mathrm{kg} / \mathrm{mes}$ en los siguientes; la pequeña alcanza máximo consumo en junio y julio de $308 \mathrm{~kg} / \mathrm{mes}$; y la gran empresa refleja un consumo constante de 216 toneladas sin variaciones considerables (Figura 2), utilizando la variedad San Luis de la empresa Marseed.

La microempresa indicó el consumo de chile chiltepín, habanero y manzano durante el periodo de enero a diciembre, con el siguiente comportamiento: en the behavior in its consumption is not constant, since it presents fluctuations of up to $191 \%$ during the year, primarily in the period from July to September. The micro-business has a maximum demand of 8.3 ton/month and minimum of 6.2 ton/month, with a variation of $33 \%$ during a year; and the small-scale business a maximum demand of $308 \mathrm{~kg} /$ month and minimum of $124 \mathrm{~kg} /$ month; the micro- and smallscale businesses have a slight upturn in the months of November and December (Figure 1). Regarding the varieties of jalapeño chili peppers that they use and require, they are: Perfecto, Seminis, Imperial from the company Marseed, Da Vinci, Chichimeca and Mitla.

With regard to the amount of demand and the purchasing months of serrano chili pepper, where the consumption is quite diverse in the three types of companies, the micro-business reaches its highest consumption in May, with $954 \mathrm{~kg} / \mathrm{month}$, and later decreases to less than $675 \mathrm{~kg} /$ month in the next ones; the small-scale business reaches maximum consumption in June and July, of $308 \mathrm{~kg} /$ month; and the large-scale business reflects a constant consumption of 216 tons without considerable variations (Figure 2), using the San Luis variety from the Marseed company.

Micro-business indicated that the consumption of chiltepín, habanero and manzano chili peppers

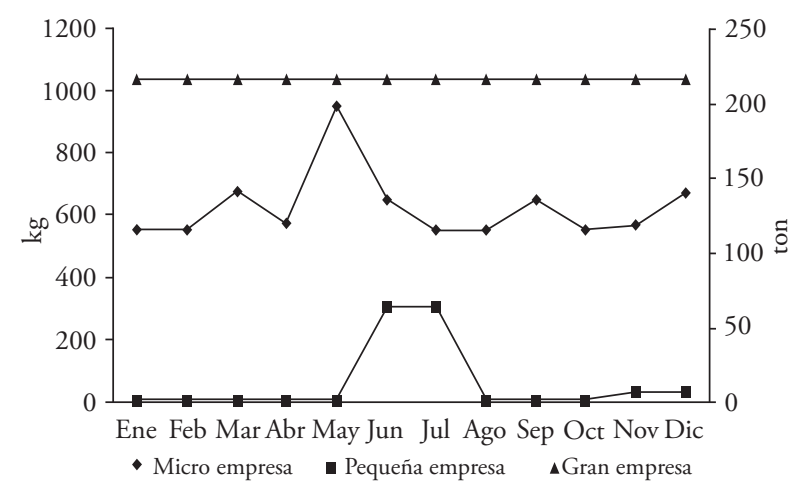

Fuente: elaboración propia con datos de la encuesta aplicada a empresas del valle de Puebla. * Source: authors' elaboration with data obtained from the survey applied to businesses in the valley of Puebla.

Figura 2. Cantidad consumida mensualmente de chile serrano por tipo de empresa, en el valle de Puebla.

Figure 2. Amount consumed monthly of serrano chili pepper per type of business, in the valley of Puebla. 
chiltepín utilizó una cantidad constante de 5.0 ton/ mes; del habanero empleó $560 \mathrm{~kg} / \mathrm{mes}$ en promedio, incrementando la cantidad a $71.4 \%$ en junio y para el manzano presentó un consumo promedio de $454 \mathrm{~kg} / \mathrm{mes}$, excepto marzo, con un incremento de $142 \%$, y para junio, septiembre y diciembre, $55 \%$.

A la cantidad de chile y los meses de consumo por parte del consumidor organizacional se suman los diferentes tipos que son utilizados. Su consumo es muy variado y depende del tamaño de la empresa, así como de la disponibilidad y del tipo de chile que emplea como materia prima, destacando el jalapeño. Esta variación del consumo obedece a la oferta por parte del principal productor de chile jalapeño, que es el estado de Chihuahua (SNIIM, 2014).

Se destaca que la gran empresa que fabrica chiles en conservas tiene un elevado consumo de chile jalapeño, serrano y chipotle. Son las variedades que más se producen y comercializan en México por su amplia aceptación por parte del consumidor final (Rodríguez, 2005). Además, la gran empresa de conserva indica las variedades que deben cultivar los productores. Esto concuerda con lo reportado por el COHCIT y OHN, 2008, que mencionan que la agroindustria recomienda a los productores sembrar determinados híbridos. Esta interacción productorempresa coadyuva en la actividad económica por el valor de la producción y los ingresos que genera por las ventas de los chiles en conserva o en fresco, tanto para el productor como para el consumidor organizacional (CONAPROCH, 2015).

En cuanto a la periodicidad de compra de chile verde se encontró que la compra más representativa en la micro y pequeña industria es cada siete días en las variedades de jalapeño, serrano y habanero. La compra de manzano es realizada semanal, quincenal y mensualmente, y el chiltepín se adquiere principalmente cada dos semanas. Lo anterior concuerda con el estudio de Villalobos y Sánchez (2013), quienes muestran que la frecuencia de compra del consumidor por productos hortícolas es de $85.3 \%$ semanalmente, a diferencia del chile seco, cuya periodicidad es mensual.

Para el caso de los atributos del chile verde el consumidor organizacional considera las siguientes propiedades como muy importantes al momento de adquirir el fruto: $95 \%$ indicó un fruto fresco y sano, $90 \%$ valoró uno exento de pudriciones y deterioro, $70 \%$ aprecia una consistencia firme, $65 \%$, during the period of January to December had the following behavior: in chiltepín, a constant amount of $5.0 \mathrm{ton} / \mathrm{month}$; in habanero, $560 \mathrm{~kg} / \mathrm{month}$ in average, increasing the amount to $71.4 \%$ in June; and in manzano, an average consumption of $454 \mathrm{~kg} /$ month, except March, with an increase of $142 \%$, and for June, September and December, $55 \%$.

To the amount of chili peppers and the months of consumption by the organizational consumer is added the different types that are used. Their consumption is very varied and depends on the size of the business, as well as on the availability and type of chili pepper they use as raw material, with jalapeño standing out. This variation in consumption obeys the offer from the main producer of jalapeño chili pepper, which is the state of Chihuahua (SNIIM, 2014).

It stands out that the large-scale business that makes chili peppers in conserve has a high consumption of jalapeño, serrano and chipotle chili peppers. They are the varieties that are produced and commercialized most in México due to their broad acceptance by the final consumer (Rodríguez, 2005). In addition, the large-scale business for conserves indicates the varieties that producers should be cultivating. This agrees with what was reported by COHCIT and OHN, 2008, which mentioned that the agribusiness recommends that producers sow specific hybrids. This producer-enterprise interaction contributes to the economic activity through the value of production and income that it generates from the sales of chili peppers in conserve or fresh, both for the producer and for the organizational consumer (CONAPROCH, 2015).

In terms of the periodicity of green chili pepper purchase, it was found that the most representative purchase in the micro- and small-scale industry is every seven days for the jalapeño, serrano and habanero varieties. The purchase of manzano is carried out by week, fortnight and month, and chiltepín is acquired primarily every two weeks. This agrees with the study by Villalobos and Sánchez (2013), who show that the purchasing frequency of the consumer for vegetable products is $85.3 \%$ weekly, compared to dry chili, whose periodicity is monthly.

For the case of the attributes of green chili pepper, the organizational consumer considers the following properties as very important at the moment of acquiring the fruit: $95 \%$ indicated a fresh and healthy fruit, $90 \%$ valued one exempt from any 


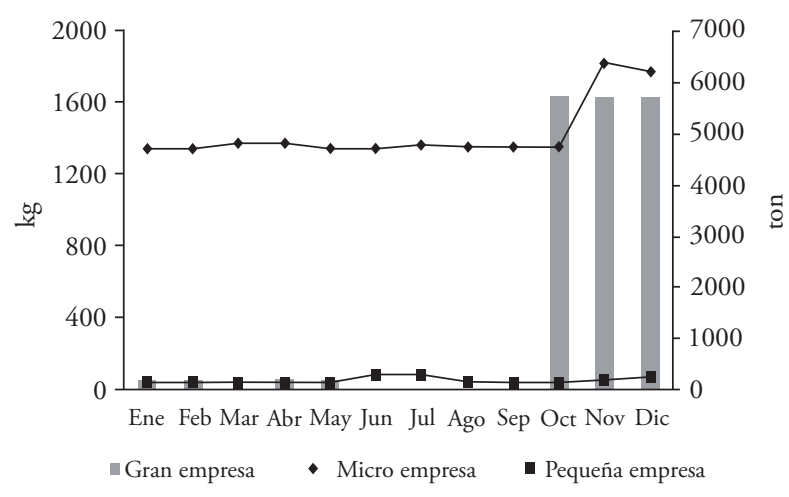

Fuente: elaboración propia con datos de la encuesta aplicada a empresas del valle de Puebla. * Source: authors' elaboration with data obtained from the survey applied to businesses in the valley of Puebla.

Figura 3. Cantidad consumida mensualmente de chile chipotle por tipo de empresa en el valle de Puebla.

Figure 3. Amount consumed monthly of chipotle chili pepper per type of business, in the valley of Puebla.

uno exento de cualquier otro olor y sabor extraños, y $60 \%$, entero y bien desarrollado. La gran industria establece condiciones en las características que deben cubrir los chiles jalapeño y serrano para su adquisición, ambos con color verde característico de fruto inmaduro; para el jalapeño, un tamaño chico y mediano; para el serrano, un promedio 1.5 y 2 pulgadas, y ambos en empaque de arpilla de rafia.

Para el chile chipotle las cantidades y los meses de consumo en las tres calificaciones de empresa (micro, pequeńa y grande) se muestran en la Figura 3. El consumo es constante para micro y pequeña empresas y en la gran empresa solo en ciertos meses del año. La micro consumió un promedio de 1.4 toneladas, incrementándose $32.8 \%$ en noviembre y $25.4 \%$ en diciembre respecto a la media; la pequeña empresa utilizó un promedio de $44 \mathrm{~kg}$ mensualmente, excepto en junio y julio que se incrementó a $84 \mathrm{~kg}$. La gran empresa consumió solo siete meses al ańo, destacando octubre, noviembre y diciembre como los de mayor consumo (5733 ton/mes).

En cuanto a la periodicidad de compra del chipotle la micro y la pequeña empresa indicaron principalmente que se realiza cada 30 días. La gran empresa mencionó un promedio de tres días por semana, correspondiente a octubre, noviembre y diciembre; además, para enero y febrero es mensual. También para esta variedad la gran empresa condiciona la adquisición y destaca: frutos sanos, color característico de other odd odor and flavor, and $60 \%$, whole and well-developed. The large-scale industry establishes conditions in the characteristics that jalapeño and serrano chili peppers should cover for their acquisition, both with the characteristic green color of immature fruit; for jalapeño, a small and medium size; for serrano, an average of 1.5 and 2 inches; and both in burlap packages.

For the chipotle chili pepper, the amounts and the months of consumption in the three business types (micro, small and large) are shown in Figure 3. The consumption is constant for micro- and smallscale businesses and in the large-scale enterprise only in certain months of the year. The microbusiness consumed an average of 1.4 ton, increasing by $32.8 \%$ in November and $25.4 \%$ in December compared to the mean; the small-scale business used an average of $44 \mathrm{~kg}$ monthly, except in June and July when it increased to $84 \mathrm{~kg}$. The large-scale business consumed only seven months per year, with October, November and December standing out as those of highest consumption (5733 ton/month).

In terms of the purchasing periodicity of chipotle, the micro- and small-scale businesses indicated primarily that it is done every 30 days. The largescale enterprise mentioned an average of three days per week, corresponding to October, November and December; in addition, for January and February it is monthly. For this variety, the large-scale business also conditions the acquisition and highlights: healthy fruits, characteristic color of smoked chili peppers, characteristic smoke odor, maximum moisture $22.99 \%$, maximum impurities $1.99 \%$, free of foreign material and packed in jute sacks.

With regard to the amount and season of consumption of the eight types of dry chili peppers used in micro-businesses (Figure 4), it was found that their consumption is constant throughout the year. The chili peppers that are used in lower amount are: serrano, $32 \mathrm{~kg} /$ month; morita, $42 \mathrm{~kg} /$ month; árbol, $89 \mathrm{~kg} /$ month; and those of highest amount are: ancho, $595 \mathrm{~kg} /$ month; pasilla, $506 \mathrm{~kg} /$ month; and mulato, $425 \mathrm{~kg} /$ month; the consumption increases in the months of November and December in the following percentages: ancho, $58 \%$; pasilla, $26 \%$; and mulato, $17 \%$; in relation to chiltepín, its consumption increases $46 \%$ in April and May. The dry chili peppers are used primarily for the elaboration of mole paste. 
chiles ahumados, olor humo característicos, humedad máxima, $22.99 \%$; impurezas máximas, $1.99 \%$, libre de material extraño y empacado en costales de yute.

Con respecto a la cantidad y época de consumo de los ocho tipos de chile secos que emplean en las microempresas (Figura 4) se encontró que su consumo es constante durante el año. Los chiles que se emplean en menor cantidad son: serrano, $32 \mathrm{~kg} /$ mes; morita, $42 \mathrm{~kg} / \mathrm{mes}$; de árbol, $89 \mathrm{~kg} / \mathrm{mes}$; y los de mayor cantidad son: chile ancho, $595 \mathrm{~kg} / \mathrm{mes}$; pasilla, $506 \mathrm{~kg} / \mathrm{mes}$ y mulato, $425 \mathrm{~kg} / \mathrm{mes}$, consumo se incrementa los meses noviembre y diciembre en los siguientes porcentajes: chile ancho, $58 \%$; pasilla, $26 \%$; y mulato, $17 \%$; en relación con el chiltepín su consumo se incrementa $46 \%$ en abril y mayo. Los chiles secos se emplean principalmente para la elaboración de pasta de mole.

La periodicidad de compra de los chiles secos es principalmente cada 30 días. Las características que prefieren en el chile ancho, mulato y pasilla son: color bien definido en café negruzco, estado fresco, sin hongos, tamaño mediano y grande, y sin manchas. A los chiles guajillo, morita, chiltepín, de árbol y serrano los prefieren de un color rojo intenso, estado fresco, bien secos, sin manchas y sin hongos.

El lugar donde se abastecen la micro y la pequeña empresa es la central de abastos de Puebla, por su cercanía, la diversidad de chiles y los precios que brinda. Asimismo, los mayoristas y minoristas de chile incurren en prácticas como:1) regar agua para que el peso se incremente, 2) regar con refresco de cola para incrementar su brillo, 3) mezclar chile nacional con extranjeros, el cual es vendido como producto nacional 4) mezclar diferentes calidades del fruto para un mayor margen de ganancia y 5) vender chile con material extraño (pedazos de pañales y plumas). A diferencia de las anteriores, la gran empresa compra directamente con el productor (agricultura por contrato) o comercializador (libre mercado) en vez de hacerlo en el lugar del origen del cultivo.

Las principales características organolépticas del chile, ya sea en verde, seco o chipotle que busca el consumidor organizacional, están basadas por la frescura, apariencia y el estado físico del producto. Lo reportado coincide con el Ministerio de Agricultura y Desarrollo Rural de Colombia (2008), quien dice que para que las empresas puedan comprarlo es necesario cumplir con ciertos requisitos, como son: ser

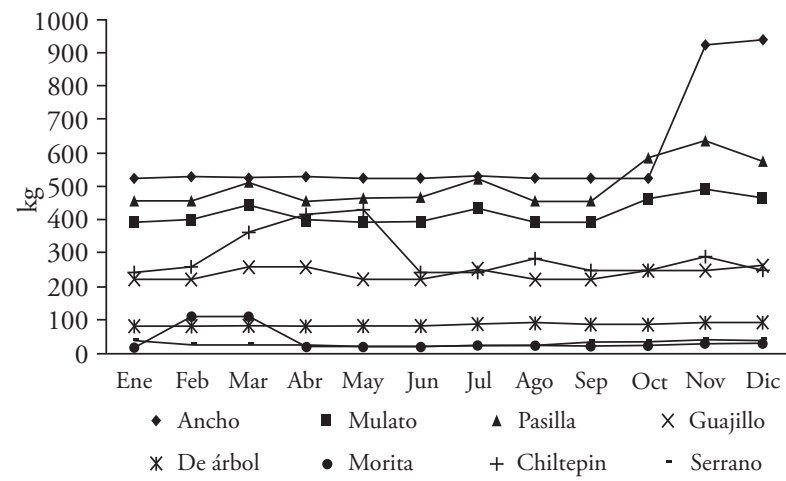

Fuente: elaboración propia con datos de la encuesta aplicada a empresas del valle de Puebla. * Source: authors' elaboration with data obtained from the survey applied to businesses in the valley of Puebla.

Figura 4. Cantidad consumida mensualmente de chile seco por la microempresa, en el valle de Puebla.

Figure 4. Amount consumed monthly of dry chili pepper by the micro-scale business, in the valley of Puebla.

The purchasing periodicity of dry chili peppers is mainly every 30 days. The characteristics that are preferred in ancho, mulato and pasilla chili peppers are: well-defined color in blackish brown, fresh state, without fungi, medium and large size, and without stains. The guajillo, morita, chiltepín, de árbol and serrano chili peppers are preferred in an intense red color, fresh state, very dry, without stains and without fungi.

The place where the micro- and small-scale businesses stocks up is the wholesale market in Puebla, because of its proximity, the diversity of chili peppers and the prices it offers. Likewise, wholesale and retail sellers incur in practices such as: 1) watering for the weight to increase, 2) spraying with cola soft-drink to increasing their shine, 3) mixing national and foreign chili peppers, and selling them as national product, 4) mixing different qualities of the fruit for a higher margin of profit, and 5) selling chili peppers with strange material (pieces of diapers and feathers). Compared to this, the large-scale business buys directly from the producer (agriculture by contract) or trader (free market) instead of doing it in the place of origin of the crop.

The main organoleptic characteristics of chili pepper, whether green, dry or chipotle, sought after by the organizational consumer are based on freshness, appearance and physical state of the product. This 
un producto de muy buena calidad en relación con la uniformidad del color, tamaño o calibre y a la fineza del fruto. Los atributos que la agroindustria busca pueden ser percibidos de acuerdo con la habilidad del consumidor y pueden categorizarse en: atributos de búsqueda y características de experiencia. Según Bello y Calvo (1998) en la primera son las que el consumidor identifica antes de la compra y puede evaluar su nivel de calidad, mientras que en la segunda pueden ser identificadas y evaluadas después de la compra. Estas habilidades del consumidor organizacional se explican debido a que son compradores expertos de su materia prima.

Cabe resaltar que en la microempresa, $75.6 \%$ desconoce el origen del fruto verde; el $57.1 \%$ no sabe la procedencia del chile seco, y $78.6 \%$ desconoce de dónde proviene el chipotle. Para la pequeña, $50 \%$ no sabe la procedencia del fruto en verde y del chipotle, y $66.7 \%$ no sabe de dónde proviene el chile seco. Por otro lado se encontró que el consumidor organizacional utiliza chile jalapeño y esencia concentrada para la fabricación de shampoo, además de chile en polvo para elaborar botanas y pimento en polvo como ingrediente en la elaboración de chorizo. Restrepo (2006) menciona que las diferentes variedades de chiles presentan concentraciones considerables de diferentes carotenoides con diversas propiedades que lo hacen un sustrato interesante para la industria alimentaria en el campo de la condimentación y la pigmentación, por lo que representan una oportunidad para diversificar el mercado de los condimentos. Esto se debe a que los consumidores han ido cambiando sus preferencias y estas se orientan a fuentes naturales y con un mínimo de adición de productos químicos o sintéticos (Pacho et al., 2002).

Respecto al lugar de compra donde acude el industrial micro y pequeño se estableció la central de abastos de Puebla como el punto principal de abastecimiento, debido a la gama de variedad de picante, precios por volumen y punto céntrico de fácil acceso. Prieto et al. (2008) mencionan que los factores que influyen en la compra son el tiempo del que dispone el consumidor, su movilidad y cercanía a centros de venta, y la distribución comercial en la localidad (mercados locales). Al respecto, el Ministerio de Agricultura y Desarrollo Rural de Colombia (2008) menciona que los principales compradores en las centrales mayoristas son los supermercados, los almacenes de cadena y, a escala industrial, los procesadores de ají en conserva y los que procesan en salsas. agrees with the Ministry of Agriculture and Rural Development in Colombia (2008), which states that in order for companies to be able to purchase it, it is necessary to fulfill certain requirements, such as: being a product of very good quality in relation to the uniformity of color, size or caliber, and finesse of the fruit. The traits that the agroindustry seeks may be perceived according to the ability of the consumer and can be categorized into: characteristics of the search and characteristics of the experience. According to Bello and Calvo (1998), the first are those that the consumer identifies before purchasing and can evaluate the level of quality, while the second can be identified and evaluated after the purchase. These abilities of the organizational consumer are explained because they are expert buyers of their raw material.

It should be highlighted that in the microbusiness, $75.6 \%$ ignore the origin of the green fruit; $57.1 \%$ don't know the origin of the dry chili pepper, and $78.6 \%$ ignore where chipotle is from. For the small-scale business, $50 \%$ does not know the origin of the green fruit and chipotle, and $66.7 \%$ does not know where the dry chili pepper is from. On the other hand, it was found that the organizational consumer uses jalapeño chili and concentrated essence to manufacture shampoo, in addition to powdered chili to elaborate snacks and powdered pimento as an ingredient in chorizo elaboration. Restrepo (2006) mentions that the different varieties of chili peppers present considerable concentrations of different carotenoids with diverse properties that make it an interesting substrate for the dietary industry in the field of seasoning and pigmentation, so they represent an opportunity to diversify the seasoning market. This is because the consumers have been changing their preferences and they are directed toward natural sources and with minimum addition of chemical or synthetic products (Pacho et al., 2002).

Concerning the place of purchase where the micro- and small-scale industrialist goes, the wholesale market in Puebla was established as the main point of supply, due to the range of variety of chili peppers, prices per volume and central point of easy access. Prieto et al. (2008) mention that the factors that influence the purchase are the time that the consumer has available, his mobility and proximity to sales centers, and the commercial 
El consumidor organizacional con clasificación micro y pequeña acude con distribuidores locales de chile para su abastecimiento, aunque no se les garantice una correcta práctica de venta. Ante estas prácticas los entrevistados expresaron su malestar e inconformidad, debido a que les ocasiona mermas y mayores costos en la manufactura de sus productos, por lo que están en constante búsqueda de proveedores que garanticen no realizar prácticas desleales. Lo anterior coincide con CONAPROCH (2015), quien menciona que la pequeña industria es un sector muy amplio y dinámico que se ha enfrentado a obstáculos, como la falta de canales de comercialización. La gran industria tiene una red de abastecimiento, principalmente con productores del norte del país, a quienes evalúa y selecciona de manera rigurosa. Un estudio del Ministerio de Agricultura y Desarrollo Rural de Colombia (2008) indica que los miembros de la alianza, los agricultores y la agroindustria implementaron proyectos seleccionados con ciertas características para mejorar la fortaleza de la alianza y la competitividad de la cadena productiva. Los agricultores deben tener experiencia en la producción de hortalizas y los suelos deben ser apropiados para el cultivo del chile y contar con disponibilidad de agua; además, los productores deben ser miembros de una organización.

Sobre el conocimiento y el interés sobre el origen del producto por parte del consumidor organizacional se observó que la micro y la pequeña empresa muestran un desinterés por conocer la procedencia del producto. Esta actitud se asocia a que no es un factor determinante para la compra del producto; lo importante son el precio y la calidad (Martín, 2006). Otros estudios han encontrado que ocho de cada diez consumidores desconocen los lugares de procedencia y la forma de transportar el producto (Alvarado et al., 2012).

Por último se determinó que $63.7 \%$ de las microempresas sí comprarían chile verde, chipotle y seco de origen regional, respectivamente. En la pequeña empresa, $66.7 \%$ que emplea chile seco está dispuesto a comprar fruto de origen poblano. El $100 \%$ de la gran empresa sí compraría picante de origen regional.

En cuanto a las variables que resultaron significativas en los coeficientes de correlación de Spearman con la intención de compra para chile verde y seco, para el primero la cercanía, la calidad y el precio fueron distribution in the locality (local markets). In this regard, the Ministry of Agriculture and Rural Development of Colombia (2008) mentions that the main buyers in wholesale centers are supermarkets, chain stores, and at the industrial scale, processors of peppers in conserve and those who process them in sauces.

The organizational consumer with classification of micro- and small-scale goes to local chili pepper distributors for their supply, although a correct sales practice is not guaranteed. In face of these practices, the interview respondents expressed their discomfort and non-conformity because it causes losses and higher costs in the manufacture of their products, which is why they are in constant search for suppliers that guarantee not performing disloyal practices. This agrees with CONAPROCH (2015), which mentions that the small-scale industry is a very broad and dynamic sector where obstacles have been faced, such as the lack of commercialization channels. The large-scale industry has a supply network, primarily with products from the north of the country, which it evaluates and selects rigorously. A study by the Minister of Agriculture and Rural Development of Colombia (2008) indicates that the members of the alliance, the farmers and the agroindustry, implemented projects selected with certain characteristics to improve the strength of the alliance and the competitiveness of the productive chain. The farmers must have experience in in vegetable production and the soils must be appropriate for the cultivation of chili pepper and have water availability; in addition, the producers must be members of an organization.

Regarding the knowledge and interest about the origin of the product by the organizational consumer, it was observed that the micro- and small-scale businesses show disinterest in understanding the origin of the product. This attitude is associated to the fact that it is not a defining factor for the purchase of the product; what is important are the price and the quality (Martín, 2006). Other studies have found that eight out of every ten consumers ignore the places of origin and the way of transporting the product (Alvarado et al., 2012).

Lastly, it was determined that $63.7 \%$ of the micro-businesses would purchase green, chipotle and dry chili peppers of regional origin, respectively. In the small-scale enterprise, $66.7 \%$ that uses dry 
significativas; y para segundo se tuvo solo la calidad y el precio (Cuadro 2). Cabe destacar que la correlación entre la intención de compra con la cercanía de los proveedores de chile seco no fue significativa. Al respecto, Adasme et al. (2006) determinaron que en la intención de compra de un producto con denominación de origen, como la frutilla, el precio es el principal atributo destacado de acuerdo a su importancia.

En este sentido, el consumidor organizacional declaró que estaría dispuesto a comprar chile producido en Puebla, siempre y cuando se cumplieran ciertas condiciones: a) variedades de chile de acuerdo con su necesidades, b) proporcionar precios competitivos, c) seguridad en el abasto y la calidad del fruto, d) ubicación céntrica para su distribución, e) de forma individual y/o colectiva con figura jurídica, f) apego a las disposiciones fiscales para facilitar deducciones de impuestos. En particular, la gran empresa que fabrica conservas de chile sumó más condicionantes para la compra de chile de origen poblano: a) sugiere que el ciclo productivo de chile jalapeńo, serrano y chipotle sea diferente a los de los estados como Chihuahua y Sinaloa, b) el producto debe cumplir con las normas de calidad e inocuidad establecidas por el gobierno mexicano y las indicadas por la misma empresa, y c) el fruto debe contar con ciertos parámetros de tamańo, elemento importante en el proceso de enlatado.

La gran empresa de conservas impone ciertas condiciones para la aceptación del chile, pacta una agricultura por contrato con los productores. En este aspecto, Eaton y Shepherd (2002) mencionan el acuerdo entre agricultores y empresas de elaboración o comercialización para la producción y abastecimiento de productos agrícolas, frecuentemente a un chili pepper is willing to purchase the fruit of origin in Puebla. In the large-scale enterprise, $100 \%$ would buy pepper of regional origin. In terms of the variables that were significant in the Spearman correlation coefficients with regard to the purchasing intention for green and dry chili pepper, for the first the proximity, the quality and the price were significant; and for the second, it was only the quality and the price (Table 2). It should be highlighted that the correlation between the purchasing intention and the proximity of the dry chili suppliers was not significant. In this regard, Adasme et al. (2006) determined that in the purchasing intention of a product with certificate of origin, such as strawberry, the price is the main attribute that stands out based on its importance.

In this sense, the organizational consumer declared that it would be willing to purchase chili pepper produced in Puebla, insofar as certain conditions are fulfilled: a) chili varieties according to their needs, b) offering competitive prices, c) security in the supply and the quality of the fruit, d) central location for its distribution, e) individually and/ or collectively with legal figure, $f$ ) adherence to the fiscal regulations to ease tax deductions. In particular, the large-scale enterprise that makes chili conserves added more conditions for the purchase of chili pepper from Puebla: a) it suggests that the productive cycle of jalapeño, serrano and chipotle chili peppers is different from that in states like Chihuahua and Sinaloa, b) the product must comply with the norms of quality and innocuousness established by the Mexican government and those indicated by the company itself, and c) the fruit must have certain

Cuadro 2. Correlación de la intención de comprar de los consumidores organizacionales con las variables de origen, precio y calidad por chile verde y seco.

Table 2. Correlation of the purchasing intention of organizational consumers with the variables of origin, price and quality for green and dry chili pepper.

\begin{tabular}{llrrr}
\hline & & Cercanía & Calidad & Precio \\
\hline \multirow{2}{*}{$\begin{array}{l}\text { Intención de compra de chile } \\
\text { verde de origen poblano }\end{array}$} & Coeficiente de correlación & $0.524^{* *}$ & $0.635^{* *}$ & $0.662^{* *}$ \\
& Sig. (bilateral) & 0.001 & 0.000 & 0.000 \\
& $\mathrm{~N}$ & 36.000 & 36.000 & 36.000 \\
\hline \multirow{2}{*}{$\begin{array}{l}\text { Intención de compra de chile seco } \\
\text { de origen poblano }\end{array}$} & Coeficiente de correlación & & $0.579^{* *}$ & $0.639^{* *}$ \\
& Sig. (bilateral) & & 0.000 & 0.000 \\
& $\mathrm{~N}$ & & 36.000 & 36.000 \\
\hline
\end{tabular}

${ }^{* *}$ La correlación es significativa en el nivel 0.01 ( 2 colas). * The correlation is significant at the level 0.01 ( 2 tails). Fuente: elaboración con datos de la encuesta aplicada a empresas del valle de Puebla. \&ource: elaborated with data from the survey applied to businesses in Valle de Puebla. 
precio, cantidad y calidad específica. Acorde con los resultados obtenidos en la región del valle de Puebla, la gran empresa otorga las plántulas de variedades específicas, envía técnicos especializados para otorgar asesorías, así como la inspección de los procedimientos de buenas prácticas de agricultor y la correcta aplicación del paquete tecnológico autorizados por la empresa. Así, la agroindustria tiene mayor control sobre la calidad de su materia prima (Macías, 2009).

\section{Conclusiones}

Existe una positiva intención de compra por parte del consumidor organizacional de chile de origen poblano, siendo la calidad y el precio las variables más significativas en la correlación Spearman. Esta intención está condicionada a la existencia de emisión de comprobantes fiscales, convenios legales, precios competitivos, tamaños específicos del fruto y aseguramiento de la calidad e inocuidad del fruto.

Las tres clasificaciones de empresa demandan esencialmente chile jalapeño, serrano y chipotle. La microempresa consume más habanero, manzano, chiltepín, ancho, mulato y pasilla. Esta demanda responde a una alternativa debido a la masificación de productos en conserva de chile por la gran industria y que demanda variedades específicas. La central de abasto de Puebla es el principal punto de abastecimiento para el consumidor con clasificación micro y pequeńa que desconoce el origen del insumo que adquiere, no así para la de la gran industria, que implementa una red de abastecimiento con productores y comercializadores para cubrir su requerimiento. Con la gran empresa es preciso promover la agricultura por contrato con los productores del estado de Puebla.

Por cada tipo de producto que elabora, la empresa demanda un tipo específico de chile. Para la elaboración de productos de conserva se requiere más chile jalapeño, serrano y chipotle. Sin embargo, el habanero, manzano y chiltepín son utilizados principalmente para la fabricación de salsas, y el ancho, mulato y pasilla están presentes en la producción de pasta para mole.

Las preferencias del consumidor organizacional para la adquisición de chile se basan en la apariencia y el estado físico. Estos aspectos en todos los casos refieren a un producto fresco, exento de pudriciones y deterioro; y consistencia firme en estado inmaduro. Para parameters of size, important element in the canning process.

The large-scale business of conserves imposes certain conditions for the acceptance of chili peppers, establishing agriculture by contract with the producers. In this regard, Eaton and Shepherd (2002) mention the agreement between farmers and enterprises for elaboration and/or commercialization for the production and supply of agricultural products, frequently in terms of a specific price, amount and quality. Based on the results obtained in the region of the valley of Puebla, the large-scale business provides seedlings of specific varieties, sends specialized technicians to offer advice, and performs the inspection of the procedures of farmer's good practices and the correct application of the technological package authorized by the company. Thus, the agroindustry has better control over the quality of its raw material (Macías, 2009).

\section{Conclusions}

There is a positive purchasing intention by the organizational consumer of chili pepper from Puebla, with the quality and the price being the most significant variables in the Spearman correlation. This intention is conditioned to the existence of the issuance of fiscal receipts, legal agreements, competitive prices, specific sizes of the fruit, and assurance of quality and innocuousness of the fruit.

The three types of businesses demand essentially jalapeño, serrano and chipotle chili peppers. The micro-business consumes more habanero, manzano, chiltepín, ancho, mulato and pasilla. This demand responds to an alternative due to the widespread distribution of chili products in conserve by the largescale industry and which demands specific varieties. The wholesale market in Puebla is the main source of supply for the consumer with micro- and small-scale classification who ignores the origin of the material he purchases, although it is not so for the large-scale industry, which implements a supply network with producers and traders to cover its requirement. With the large-scale business it is necessary to promote agriculture by contract with the producers in the state of Puebla.

For each type of product it makes, the enterprise demands a specific type of chili pepper. For the elaboration of products in conserve, more jalapeño, 
el chile seco se refiere a color bien definido, exento de hongos y manchas. Así, las preferencias del consumidor organizacional tipo industrial dan las pautas sobre las características del chile que los productores deben producir, considerando cada segmento del mercado (micro, pequeña y gran empresa). Además, será recomendable que las instituciones de investigación generen variedades de chile que el consumidor organizacional demanda, es decir, variedades más precoces y de tamaño y color estandarizado. Otro elemento importante para garantizar las condiciones de calidad en que los chiles llegan al mercado es el manejo post cosecha y la logística de mercadeo.

\section{Literatura Citada}

Adasme, C., A. Spiller, y J. Diaz. 2006. Determinación de Preferencias del Consumidor de la Región Metropolitana hacia la frutilla blanca (Fragaria chiloensis). Un Análisis Conjunto y una Prueba Sensorial. Economía Agraria. 10: 1-10.

Alvarado, L.E., J. R. Luyando, y R. Téllez. 2012. Caracterización del consumidor de la carne de pollo en el área metropolitana de Monterrey. Región y Sociedad. 24 (54): 175-199.

Armstrong, G., y Kotler P. 2003. Marketing: an introduction. New Jersey, Pearson education Inc.

Bello, A. L., y D. Calvo. 1998. Propuesta de un modelo positivo del proceso de compra de carne de ternera y evaluación de las preferencias de los consumidores. Economía Agraria. 183: 201-220.

Castellón, M. E., J. L. Chávez., J. C. Carrillo, y A. M. Vera. 2012. Preferencias de consumo de chiles (Capsicum annuum L.) nativos en los valles centrales de Oaxaca, México. Revista Fitotecnia Mexicana. 35: 27-35.

Chu, C. W., and Lu H. P. 2007. Factors influencing online music purchase intention in Taiwan: An empirical study based on the value-intention framework. Internet Research. 17: 139155.

COHCIT (Consejo Hondureño de Ciencia y Tecnología) y OHN (Organismos Hondureño de Normalización). 2008. Estudio de Mercado Chile Jalapeño Capsicum annum L. Tegucigalpa. pp: 23-24.

CONAPROCH (Comité Nacional Sistema Producto Chile AC). 2015. Plan Estratégico Nacional para el Desarrollo del Sector de Producción Primaria en el Cultivo. Texto completo en http://www.conaproch.com/descargas/Proyecto_Plan_Estrategico_2015.pdf. Consultado septiembre 2015.

Eaton, C., y W. A. Shepherd. 2002. Agricultura por contrato. Alianzas para el crecimiento. Boletín de Servicios Agrícolas de la FAO. No. 145. serrano and chipotle peppers are needed. However, habanero, manzano and chiltepín are used primarily for the fabrication of sauces, and ancho, mulato and pasilla are present in the production of paste for mole.

The preferences of the organizational consumer for the acquisition of chili peppers are based on the appearance and physical state. These aspects in every case refer to a fresh product, free of rotting and deterioration; and firm consistency while immature. For the dry chili pepper, they refer to well-defined color, exempt of fungi and stains. Thus, the preferences of the organizational consumer of industrial type give the standards for the characteristics of chili peppers that the producers must produce, considering each segment of the market (micro-, small-, and largescale enterprise). In addition, it will be advisable for research institutions to generate chili varieties that the organizational consumer demands, that is, more precocious varieties and with standardized size and color. Another important element to guarantee the conditions of quality of chili peppers that reach the market is the post-harvest management and logistics of trade.

$$
\text { - End of the English version - }
$$

FAOSTAT (Food and Agriculture Organization of the United Nations). 2014. Texto completo en http://faostat3.fao.org/ browse/Q/QC/S. Consultado mayo 2015.

Galindo G., G. 2007 El servicio de asistencia técnica a los productores de chile seco en Zacatecas. Convergencia. Revista de Ciencias Sociales. 14 (43): 137-165.

García, Yi. J. 2013. Segmentación del mercado de ajíes nativos subutilizados mediante modelos de Poisson y Probit ordenados en Lima, Perú. Agroalimentaria. 19 (37): 91-108. Universidad de los Andes Mérida, Venezuela.

Grewal, D., R. Krishnan, J. Baker, y N. Borin. 1998. The Effect of Store Name, Brand Name and Price Discounts on Consumer's Evaluations and Purchase Intentions. Journal of Retailing. 74 (3): 331-352.

Grunert, K. G. 1989. Attributes, attribute values and their characteristics: A unifying approach and an example involving a complex household investment, Journal of Economic Psychology. 10 (2): 229-262

Hernández, S. R., C. Fernández, y P. Baptista. 2010. Metodología de la investigación. 5ª ed. México, D.F: Mc Graw Hill.

Huerta de la Peńa, A., y J. L. Jaramillo. 2010. Manual de buenas 
prácticas agrícolas y de manejo del chile poblano. Puebla: Colegio de Postgraduados Campus Puebla-Fundación Produce Puebla-Altres Acosta-AMIC Editores.

INEGI (Instituto Nacional de Geografía Estadística e Informática). 2012. Directorio Estadístico Nacional de Unidades Económicas 2012. http://www.inegi.org.mx/est/contenidos/proyectos/denue/presentacion.aspx. Consultado en junio 2013.

INEGI (Instituto Nacional de Geografía Estadística e Informática). 2014. Censos Económicos. Resultados oportunos del estado de Puebla 2014. http://www. inegi.org.mx. Estadística/Fuente/Proyecto/Censos económicos. Consultado en julio 2015.

INEGI (Instituto Nacional de Geografía Estadística e Informática). 1995. Censos Económicos. Marco Geo estadístico.

Jäger M, A. Jiménez, y K. Amaya (comp). 2013. Guía de oportunidades de mercado para los ajíes nativos de Perú. Compilación de los estudios realizados dentro del marco del proyecto Rescate y Promoción de Ajíes Nativos en su Centro de Origen para Perú. Bioversity International. Cali, Colombia. pp: 4-66.

Kotler, P., Amstrong, G., Cámara, D., y Cruz, I. 2004. Marketing. Madrid: Pearson Educación S. A.

Kotler, P., and K. L. Keller. 2009. Marketing Management. New Jersey: Pearson Education, Inc.

Macías, M. A. 2009. Mallas de valor global en la agricultura de hortalizas en México. El caso de Sayula, Jalisco. Región y Sociedad. 21 (46):113-144.

Mannarelli, V. B. 1978. Notas sobre mercado de productos agropecuarios. Determinación de pérdidas de post-cosecha de alimentos causadas por insectos: algunos comentarios. Bogotá. Colombia. 18 p.

Manrique M. L. F. 2014. Comportamiento de compra organizacional, una exploración del estado actual. Revista Virtual Universidad Católica del Norte. 43:113-130.

Martín, C. V. J. 2006. Hábitos de compra y consumo de frutas y hortalizas. Distribución y Consumo. pp: 5 -28.

Ministerio de Agricultura y Desarrollo Rural de Colombia. 2008. Análisis de Agro Alianza Productiva y Comercial Ají. Texto completo en http://www.misionrural.net/observatorio/alianzas/productos/aji/7muni-valle/preinversion.pdf. Consultado septiembre 2015 .

Montes, S., E. Heredia, y A. Aguirre. 2004. Fenología del cultivo del chile (Capsicum annuum L.). Cultivo y recursos genéticos. Primera convención mundial de chile. León y Celaya, Guanajuato, México, Junio 2004. pp: 23-27.

Morwitz, V. G., y D. Schmittlein. 1992. Using Segmentation to Improve Sales Forecasts Based on Purchase Intent: Which Intenders Actually Buy. Journal of Marketing Research. 29 (4): 391-405.
Ortega, Z. J. 2013. Primer Festival de Chiles, Salsas y Molcajetes en el Centro Comunitario Ex Convento de Culhuacán de INAH. Texto disponible http://www.inah.gob.mx/ es/boletines/3008-chiles-salsas-y-molcajetes-en-culhuacan. Consultado enero 2015.

Pacho, C. J. D., R. M. Domínguez., C. G. Cantón., A. Ponsich., R. Turner., G. Manzanilla, y C. Poot. 2002. Diseño conceptual de una planta de extracción de oleorresina: Capsicum y capsaicina a partir de chile habanero (Capsicum chinense) usando CO2 supercrítico. Tecnología, Ciencia Educación (IMIQ). 17 (2): 95-103

Peña, G. N. 2014. El valor percibido y la confianza como antecedentes de la intención de compra online: el caso colombiano. Cuadernos de Administración. Universidad del Valle. 30 (51):15-24.

Prieto, M., J. M. Mouwen, S. López, y A. Cerdeño. 2008. .Concepto de calidad en la industria Agroalimentaria. Interciencia. 33 (4):258-264.

Restrepo G. M. 2006. Oleorresinas de capsicum en la industria alimentaria. Revistas Lasallista de Investigación. 3 (2): 4347.

Rodríguez, L. A. 2005. Preferencia del consumidor por el chile piquín en comparación con otros chiles en el noreste de México. Rev. Chapingo S. Hort. 11 (2): 279-281.

Rodríguez, L. A., O. P. Campodónico, M. Ramírez, F. J. Silva, R. Zúñiga, R. Sánchez, T. Medina, y H. Villalón. 2002. Effect of shading on growth and yield of 10 accessions of piquin pepper (Capsicum annuum L. var aviculare) in four locations of northeastern Mexico. Proceedings $16^{\text {th }}$ International Pepper Conference. Tampico, Tamps. México. 63 p.

SAGARPA (Secretaría de Agricultura, Ganadería, Desarrollo Rural, Pesca y Alimentación. Servicio de Información Agroalimentaria y Pesquera). 2010. Anuario estadístico de la producción agrícola de los Estados Unidos Mexicanos 2010. http://www.siap.gob.mx/cierre-de-la-produccion-agricolapor-estado/. Consultado enero 2014

SAGARPA (Secretaría de Agricultura, Ganadería, Desarrollo Rural, Pesca y Alimentación. Servicio de Información Agroalimentaria y Pesquera) 2012. Anuario estadístico de la producción agrícola de los Estados Unidos Mexicanos 2012. http://www.siap.gob.mx/cierre-de-la-produccion-agricolapor-estado/. Consultado en mayo 2014

Schiffman, L., and L. Kanuk. 2010. Comportamiento del consumidor. Décima Edición. México. Prentice Hall. 16 p.

Sharon L. L. 2000. Muestreo: Diseño y Análisis. International Thomson Editores S.A. de C.V. México. 475 p.

Secretaria de Economía. Sistema de Información Empresarial Mexicano. 2013. http://www.siem.gob.mx. Consultado junio 2013. 
SNIIM (Sistema Nacional de Información e Integración de Mercados). 2014. Disponible en Internet: http://www.economia-sniim.gob.mx/2010prueba/Concentrado.asp?dqDia $=1 \& \mathrm{dqMes}=1 \& \mathrm{dq}$ Anio=2015\&aqDia=31 \&aqMes=12\&aq Anio $=2015 \&$ Prod $=233 \& E d o=\&$ punto $=\&$ det. Consultado agostos 2015.

Solé, M. Ma. L. 2003. Los consumidores del siglo XXI. España. Segunda Edición. ESIC EDITORIAL. 18 p.

Solomon, Michael R. 2013 Comportamiento del consumidor. Décima edición, Pearson Education. México. 640 p.
Soto, A. D., E. Witting de P., L. Guerrero, F. Garrido, y R. Fuenzalida. 2006. Alimentos Funcionales: Comportamiento del Consumidor Chileno. Revista chilena de nutrición. 33 (1):43-54

Villalobos, M. A.. y C. L. Sánchez. 2013. Caracterización del consumo de hortalizas en las familias del sur-sur de Costa Rica. Agronomía Mesoamericana 24(1): 37-46. 